BIORHEOLOGY, 25; $917-918,1988$

$0006-355 \mathrm{X} / 88 \$ 3.00+.00$ Printed in the USA.

Copyright (c) 1988 Pergamon Press plc. All rights reserved.

\title{
CONTENTS OF CLINICAL HEMORHEOLOGY, VOLUME 8, NUMBER 5
}

VOLUME 8, NUMBER 5

Contents

A.L. Copley and S. Witte
A.L. Copley

A.L. Copley

J.A. Dormandy and E. Ernst

H.A. Zondervon, M.R. Hardeman, L.L.M. Thomas, M.E. Smorenberg-Schoor and P.E. Treffers

M.R. Hardeman, R.M. Bauersachs and H.J. Meiselman

R.R. Puniyani, V.S. Agashe, V. Annapurna and S.R. Daga

R. Agosti, M. D'Ettorre, P. Cherubini, A. Clivati, M. Bozzoni and E. Longhini

L.C. Cerny, E.L. Cerny, C.L. Cerny,

M. Reath, M. Liszczynskyj and S. Gabel

C.S. Johnson, M.C. Sowter, P.C.W. Stone,

A.J. Keidan and J. Stuart

Y.Y. Bilto, M. Player and J. Stuart

R.R. Puniyani, V. Annapurna and V.S. Jaiswal

Shi Yong-de and Lian Ze-jun

F. Driss, Ph. Darcet, N. Delhaye and F. Mendy

M. Boynard, M. Razavian and Y. Beuzard

D. Koutsouris, M. Boynard,

E. Delatour-Hanss and L. Gattegno
543 Editorial

546 Dedication

Obituary

547 In Memoriam: George William Scott Blair (1902-1987)

Obituary

569 Arpad Matrai (1949-1988)

Papers

571 Failure of hemorheological intervention: Isovolemic hemodilution did not prevent early intra-uterine fetal death

581 RBC laser diffractometry and RBC aggregometry with a rotational viscometer: Comparison with rheoscope and Myrenne Aggregometer

595 Haemorheological profile in cases of chronic infections

603 New aspects of erythrocyte aggregation

621 Some potential blood substitutes

637 Action of cetiedil citrate and oxpentifylline on deformability of sickle cells dehydrated by hyperosmolar stress

649 Action of cetiedil citrate on the cation content, deformability, and osmotic fragility of human erythrocytes

663 Haemorheological changes in allergic skin disorders

669 An equation relating erythrocyte sedimentation rate (ESR) to hematocrit (HCT) and its implication

679 Effect of eicosapentaenoic acid on RBC filterability and fatty acid composition

687 Evaluation of sickle cell aggregation by ultrasound backscattering

695 Rheological properties of desialylated erythrocytes studied by ultrasound backscattering and filtration 
(Continued from outside back cover)

E. Friederichs, M. Lakomek, H. Winkler and $\mathrm{W}$. Tillmann

E. Muralidharan and M. Singh

A. Craveri, C. Tornaghi, L. Paganardi, R. Ranieri, S. Scaglioni, M. Torchiana and M. Giovannini

T. Di Perri, F. Laghi Pasini, L. Ralli, S. Pecchi, V. De Franco, P. Damiani, L. Domini, M. Materazzi, A. Monaci,

M. Franchi, A. Burresi, F. Landini,

D. Pieragalli, A. Acciavatti, C. Galigani,

C. Frigerio, G.I.. Messa, P. Blardi and l. Volpi

A.A. Kaperonis and S. Chien

P. Költringer, (). Eber, P. L.ind, (j. Klima and $V$. Ribitsch

A. Vaya, J. Aznar, P. Villa, J. Valles,

M.T. Santos and V. Martinez-Sales

P.C.W. Stone, S.M. Chalder and J. Stuar

E. Ernst, Ch. Schmidlechner, A. Matrai and H. Bergmann

T. Wegener and B. Sandhagen

D. Norcliffe and M.J. Brown

E. Ernst
707 Effects of calcium ions and 2,3-diphosphoglycerate on the solubility of deoxygenated human hemoglobin

715 Influence of diabetes mellitus and myocardial infarction on erythrocyte sedimentation profiles as determined by He-Ne laser light scanner

723 Hemorheological changes in obesity

737 Effect of controlled physical activity on haemorheological and metabolic changes in POAI) patients

751 Blood rheology and red cell metabolism in the menstrual cycle in normal and heteroygeus thalassemic women

763 Hypervolemic short-time hemodilution: Longtime observation of hemorheological parameters

773 Erythrocyte filterability in patients with cerebrovascular insufficiency. Effect of pentoxifylline and dipyridamole. Preliminary results

779 Action of piracetam on cation flux and deformability of sickle celis

Brief Communicutions

791 Snoring and blood rheology

793 N-acetylcysteine reduces the viscosity of macroglobulinaemic plasma in vitro

797 An evaluation of 'Tk' as an indicator of red cell rigidity

801 Announcements

805 Errata

807 Literature Survey

815 Contents of BIORHEOL.OGiY, Volume 25 , Number $1 / 2$ and Number 3 